\title{
Entrepreneurial Behavior During Industry Emergence: An Unconventional Study of Discovery and Creation in the Early PC Industry
}

\author{
Alka Gupta \\ Christoph Streb \\ Vishal K. Gupta \\ Erik Markin
}

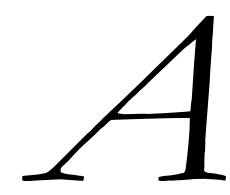
cting entrepreneurially in nascent industries is a complex endeavor characterized by uncertainty and ambiguity. Nevertheless, entirely new industries do emerge, often as a direct result of entrepreneurial behavior. We extend and apply discovery and creation approaches to study entrepreneurial behavior during industry emergence by means of qualitative analysis of a film about the personal computer (PC) industry's formative years. We find that discovery and creation behavior are fundamentally interrelated and share a common element: bricolage. Moreover, ideological activism is a major component of entrepreneurial behavior in a new industry's formative years during both creation and discovery processes. Implications for research and practice are discussed.

Keywords: entrepreneurial behavior, discovery, creation, qualitative methodology

Entrepreneurial behavior is "risky business" under any condition, but especially during an industry's formative years when there are few precedents for the kinds of activities in which enterprising actors want to engage (Sine, Haveman, \& Tolbert, 2005). Nevertheless, entirely new industries emerge successfully, often as a direct result of human agency (Garud \& Karnoe, 2003). Studies of entrepreneurial behavior have tended to concentrate on relatively mature industries where its dynamics may differ (Mezias \& Kuperman, 2001), resulting in "the persistence of major gaps in our understanding" of the phenomenon (Forbes \& Kirsch, 2011). This lack of studies on entrepreneurial behavior in emergent industries is a notable omission. Not only is entrepreneurial behavior an important research topic in its own right, but events and activities during this time also tend to have a profound impact on an industry's subsequent development (Aldrich \& Reuf, 2006). In our study, we begin to redress this research gap. We extend prior research and empirically apply discovery and creation perspectives to study entrepreneurial behavior during industry emergence through a narrative analysis of a 1999 made-for-TV film, Pirates of Silicon Valley (henceforth PSV), which documents the activities of a variety of actors involved in the emergence of the personal computer (PC) industry (Leonard, 1999).

At present, the literature presents two perspectives-discovery and creation-that explicitly address the role of agency and action in entrepreneurship (Alvarez \& Barney, 2007). For discovery theorists, alert actors identify hitherto unperceived discrepancies that can be readily rectified (Kirzner, 1997; Shane, 2003). For creation theorists, imaginative actors create new artifacts (Mathews, 2010; Sarasvathy, 2001). In metaphorical terms, discovery is about "searching the brushy woods for a choice of path," while creation involves constructing new paths (Hjorth \& Johannisson, 2008: 343). For the most part, these two theoretical perspectives have been considered opposed to each other in the prior literature. Despite the increasing popularity of discovery and creation approaches in entrepreneurship (Edelman \& Yli-Renko, 2010; Vaghely \& Julien, 2010), these two perspectives have not been explicitly used to provide insights into entrepreneurial behavior in emergent industry contexts (Bird \& Schjoedt, 2009). We therefore apply these perspectives, with the goal of comparing and contrasting them to advance our understanding of entrepreneurial behavior under conditions of uncertainty and ambiguity (Alvarez \& Barney, 2010).

The film PSV is based on careful research that involved digging through "reams of documents dating back to the 1970s," reading "all available books about those involved" in the process, combing through old magazine pieces written as events were unfolding, and viewing "miles of film and video footage" related to the main characters (Huff, 1999). Steve Wozniak, a key figure in the development of Silicon Valley and a co-founder of Apple Inc., provided an industry insider endorsement of the film (Korsgaard \& Neergaard, 2011) when he declared that it "pretty much reflected the events as they happened" (Wozniak, 2000). This is not to say that 
PSV, like other entrepreneurship stories, may not take some artistic license, substituting - in Gartner's words (2007: 614)_- "unknowns in the knowledge of specific 'facts as given' with 'facts as made."' It nevertheless serves as a rich source of information to generate insights into entrepreneurial behavior (Gartner, 2010a). Ahl and Czarniawska (2010: 196) argue that even if an entrepreneurship story is not completely authentic, it can still advance the study of entrepreneurial behavior as long as "it is interesting to analyze."

In the present study, we deploy discovery and creation theories to cast new light on industry emergence using PSV as a key source of information about the formative years of the PC industry. We advance knowledge about entrepreneurial behavior during industry emergence in several ways. First, the discovery and creation perspectives that we employ not only allow us to examine and apply theoretical tenets from existing perspectives, but also to develop theoretically grounded insights into entrepreneurial behavior in an emergent industry context (Aldrich \& Reuf, 2006). Forbes and Kirsch (2011: 4) contend that industry emergence represents the "left side of a story whose center and right are comparatively well documented" in the organizational literature. Our use of two established theoretical frameworks-discovery and creation-seeks to shed new light on entrepreneurial behavior in a nascent industry context.

Second, we use a qualitative approach to provide a context-rich empirical analysis of entrepreneurial behavior (Gartner, 2010a; Hjorth, Jones, \& Gartner, 2008). Our approach involves a holistic interpretation of the recorded activities and processes comprising entrepreneurial behavior (Phillips \& Brown, 1993), which makes this approach suitable for research in entrepreneurship (Chiles, Vultee, Gupta, Greening \& Tuggle, 2010a). Although researchers have long viewed qualitative research with indifference, skepticism, and even disdain, it is gradually gaining respectability in entrepreneurship and is expected to become more prominent (Gartner, 2007), so that some scholars now consider such research crucial for knowledge generation in entrepreneurship (Gartner, 2010b; Steyaert, 2007). The detail, drama, and surprise that characterize qualitative studies provide contextualization and intensity of experience that entrepreneurship researchers believe helps theory development in their field (Fletcher, 2007; Hjorth \& Johannisson, 2008; Teague, 2010).

Third, although stories about entrepreneurial behavior abound in contemporary society (Fletcher, 2007), such stories have traditionally been ignored in entrepreneurship scholarship (Ahl \& Czarniawska, 2010). This neglect has begun to change in recent years with scholars beginning to appreciate the value of entrepreneurship stories in biographical accounts (e.g., The Toy Stor(e)y in Gartner, 2007) and books (e.g., Republic of Tea in Gartner, 2010b). Despite this increase in the use of "stories as data" (Gartner, 2010a), films have not yet entered the repertoire of scholars in our field. This is surprising, because film presents a story as a "sequence of events connected by subject matter and related by time" (Scholes, 1980: 209). In addition, films are important cultural and educational artifacts, and have a "pervasive and enduring presence" in modern society (Neuendorf et al., 2010: 759). Our use of a film that is readily available for future study thus has the potential to extend story-based entrepreneurship research (e.g., Gartner, 2007, 2010b) in new directions (Gartner, 2010a).

\section{Theoretical Background}

\section{Discovery and Creation Perspectives}

Discovery and creation frameworks can be considered meta-perspectives comprising a wide variety of entrepreneurship research based on underlying philosophical assumptions (Chiles et al., 2010a; Zahra, 2008). Although both perspectives are rooted in fundamentally different assumptions about the nature of the market process (Gloria-Palermo, 1999), they embrace the idea that the economy is driven by enterprising actors' spontaneous actions (O’Driscoll \& Rizzo, 1985). The discovery perspective assumes a realist objective ontology, whereas the creation perspective is rooted in subjective constructivist ontology (Pacheco, Dean, \& Payne, 2010). The former posits that the world is comprised of objective phenomena to which entrepreneurs respond actively (Kirzner, 1997; Shane \& Venkataraman, 2000), while the latter contends that entrepreneurial action continually constructs the world (Chiles, Tuggle, McMullen, Bierman \& Greening, 2010b). In contemporary entrepreneurship research, discovery is associated with the work of, for example, Shane (2000) and Busenitz (1996); creation is associated with entrepreneurship in the work of Sarasvathy (2001) and Chiles and Zarankin (2005).

In recent years, discovery and creation have emerged as credible alternatives to traditional neoclassical models that provided a limited - if any-role for entrepreneurial behavior in the economy (Klein, 2008). Both the discovery and creation approaches spotlight entrepreneurs as enterprising agents who introduce new products and services to the world (Zahra, 2008), and celebrate entrepreneurial behavior as an engine for economic development (Miller, 2007). Table 1 presents a summary comparison of the two perspectives as they pertain to entrepreneurship. 
Table 1. Comparing Discovery and Creation Approaches

\begin{tabular}{lll}
\hline \multicolumn{1}{c}{ Key Elements } & \multicolumn{1}{c}{ Discovery Approach } & \multicolumn{1}{c}{ Creation Approach } \\
\hline Philosophical Paradigm & Objective realist ontology & Subjective constructivist ontology \\
\hline Key Entrepreneurial Facility & Alertness & Imagination \\
\hline Position on Agency & Formulaic & Bricolage \\
\hline View of Opportunity & Objective, hidden: waiting to be discovered & $\begin{array}{l}\text { Enacted, constructed: created through } \\
\text { action }\end{array}$ \\
\hline Locus of Subjectivity & Knowledge based on previous experience & Conjecture based on future expectations \\
\hline Source of Change & Exogenous shocks & $\begin{array}{l}\text { Endogenous, by entrepreneurs in an } \\
\text { evolutionary, path-dependent manner }\end{array}$ \\
\hline Nature of Planning & Causation & Effectuation \\
\hline Market System & Equilibrating & Disequilibrating \\
\hline Nature of Evolution & Path dependence & Path creation \\
\hline Decision-making Setting & Risky & Uncertain \\
\hline Representative Authors & Busenitz (1996); Shane (2000); Gaglio and & $\begin{array}{l}\text { Baker and Nelson (2005); Chiles, Blue- } \\
\text { dorn, and Gupta (2007); Sarasvathy (2001) }\end{array}$ \\
\hline
\end{tabular}

As can be seen in Table 1, a key aspect of the discovery approach is alertness, whereas in the creation approach the focus is on imagination. The former involves scanning the environment to identify pre-existing means-end asymmetries (Sarasvathy, Dew, Velamuri, \& Venkataraman, 2003), while the latter involves bringing into being new means and/ or ends (Buchanan \& Vanberg, 1991). From a discovery perspective, action is based on the interpretation of past experiences (Shane, 2000) while, from a creation lens, action is driven by expectations about an unknown future (Chiles et al, 2010b). In the discovery view, change occurs as a result of exogenous "shocks" beyond one's control, while in the creation view change is brought about by purposeful acts (Vaughn, 1992). Discovery theorists encourage entrepreneurs to identify and analyze alternatives selecting one with highest expected returns (Fiet, 1996), whereas creation theorists advocate gradual commitments and experimentation (Sarasvathy, 2001). The former emphasizes formulaic agency (combining things in a predetermined manner), while the latter brings bricolage (making do with resources at hand) center-stage. In discovery, entrepreneurship is path-dependent ("where one can be depends on where one has been"), and in creation it is path-generative ("where one can be depends on where one wants to be") (Garud \& Karnoe, 2003).
To date, theoretical and empirical research on discovery and creation has largely centered on the opportunity concept (e.g., Zahra, 2008; Sarasvathy, Dew, Velamuri, \& Venkatarman, 2003). Entrepreneurship scholars have used discovery and creation to examine business opportunities in Canadian smalland medium-sized enterprises (Vaghely \& Julien, 2010), Swedish mobile Internet entrepreneurs (Berglund, 2007), and small ventures in the US (Edelman \& Yli-Renko, 2010). While such studies have taught us much about the nature of business opportunities, they do not go far enough to explore the broader domain of entrepreneurial behavior. This is an important shortcoming in prior research, since it is possible that when it comes to entrepreneurial behavior, discovery and creation operate differently than in the realm of opportunity. We advance Alvarez and Barney's (2007) initial attempt to extend the scope of discovery and creation perspectives. Specifically, we examine and apply discovery and creation in the realm of entrepreneurial behavior, moving beyond their limited application to business opportunity. A number of researchers in entrepreneurship and organizational studies have noted that discovery and creation theories offer distinct insights into entrepreneurship phenomenon (Santos \& Eisenhardt, 2009; Kor, Mahoney, \& Michael, 2007; Pacheco, Dean, \& Payne, 2010; Vaghely \& Julien, 2010). 


\section{Entrepreneurial Behavior in Emergent Industries}

Although some may argue otherwise, it seems evident that much of what we consider entrepreneurship involves intentional entrepreneurial behavior (Krueger, O’Reilly, \& Carsrud, 2000). Defined broadly, entrepreneurial behavior encompasses activities and events that enterprising actors enact to pursue an entrepreneurial path (Bird \& Schjoedt, 2009). By definition, behavior is concrete, not abstract, and can be seen and/or heard.

An example of such concrete behavior is found in the short story, $A$ Toy Store (y), which is a retrospective account of a toy retailing endeavor and recently the centerpiece of a special journal issue on narrative research in entrepreneurship (Allen, 2007). In this engaging business story, an enterprising team starts a venture selling toys, confronts several obstacles in the process, and cashes out after some weeks (Fletcher, 2007). The story describes the various activities and milestones such as taking out loans, leasing commercial space, obtaining merchandise, running promotions, acquiring customers, and outsmarting competitors (Allen, 2007). When interpreted and understood in the context of the story as a whole, these actions provide rich insights into the concept of entrepreneurial behavior (Gartner, 2007). Together, these activities, each of which can be broken down into its constituent elements (e.g., taking out a loan involves meeting with a banker, completing an application, etc.), constitute the entrepreneurial process.

It is a truism that entrepreneurial behavior is risky (Sine, Haveman, \& Tolbert, 2005). In emerging industries, the level of risk is exacerbated as the public and resource providers are unfamiliar with and skeptical about new market offerings (Sarasvathy, 2001). Nevertheless, in the past few decades, various new industries (e.g., the PC industry) have emerged, providing employment, producing wealth, and fostering economic development (Garud \& Karone, 2003). The successful emergence of new industries is remarkable, considering that many nascent industries never manage to emerge, remain dormant for decades, or meet a conclusive death at some point. (Forbes \& Kirsch, 2011). Despite disagreements about the precise temporal boundaries of industry emergence, there is a general consensus that emergence refers to a new industry's formative years, concluding with maturity or stability (Aldrich and Reuf, 2006). In terms of time, it may take a new industry anywhere from one or two years to more than fifty to get to a stage where its dominant logic is widely accepted (Klepper \& Graddy, 1990), at which point it is considered an established industry (Mezias \& Kuperman, 2001).
Ambiguity-defined as a "lack of clarity about the meaning and implications of particular events or situations" due to unknown patterns of relationships and actions (Santos \& Eisenhardt, 2009: 644)—is a characteristic feature of emergent industries. Ambiguity in emerging industries can be contrasted with the inability to predict the probability of specific outcomes in established industries that have a widely accepted dominant logic (Sarasvathy, Dew, Velamuri, \& Venkataraman, 2003). Specifically, emerging industries offer fertile ground for entrepreneurial action, as enterprising actors test new ideas that are retained, discarded, or refined, depending on market responses (Sine \& Lee, 2009).

The undefined structure and multiple possible cause-effect relationships characterizing emerging industries facilitate new interpretations that reduce their inherent ambiguity (Santos \& Eisenhardt, 2009). Weick (1995: 95) argues that there are two possible responses to ambiguity: "Ambiguity understood as confusion created by multiple meanings calls for ... construction [and] ambiguity understood as ignorance created by insufficient information calls for ... discovery." Building on this insight, we suggest that insights into entrepreneurial behavior during industry emergence may emerge from discovery and creation perspectives (Alvarez \& Barney, 2007; 2010).

More than four decades ago, Baumol (1968: 66) observed that the entrepreneurial actor- "the Prince of Denmark" - is absent "from the discussion of Hamlet." Twenty years later, Low and Macmillan's (1988) seminal article urged researchers to study entrepreneurial behavior on the part of enterprising actors to understand and explain entrepreneurship. This new focus posed certain challenges: entrepreneurial behavior tends to be idiosyncratic, rare, and unpredictable (Macmillan \& Katz, 1992), making it difficult to conceptualize and study empirically. Indeed, in their recent review of the extant literature on entrepreneurial behavior published twenty years after Low and Macmillan (1988), Bird and Schjoedt (2009: 334) observed "a paucity of empirical research and a lack of conceptual clarity" in the area. Thus, despite its value as a "fertile and unique intellectual space" (Low, 2001: 22), scholarly understanding of entrepreneurial behavior in emergent industries remains limited (Krueger, Reilly, \& Carsrud, 2000). We hold that the application of welldeveloped theoretical frameworks such as discovery and creation would be helpful in overcoming this problem.

We note that the present study is located in the growing research stream illuminating entrepreneurial behavior during a new industry's formative years (Forbes \& Kirsch, 2011). Aldrich and Fiol (1994: 645) 
observed that during the early years, entrepreneurial behavior involves navigating "at best, an institutional vacuum of indifferent munificence" and, at worst, "a hostile environment impervious to [entrepreneurial] action." Despite these challenges, substantial entrepreneurial activity does occur in nascent industries (Forbes \& Kirsch, 2011). Event-driven methods are required to capture the salient features of behavior that unfolds over time during industry emergence (Van de Ven \& Engelman, 2004). Such methods employ narrative explanations to address how rare and unpredictable events - in this case, acts of entrepreneurial behavior - occur, and then relate these specific activities to the big picture (Chiles et al., 2010a). The methodological approach we use emphasizes the need to interpret specific events in the broader context in which they occur, and to understand the larger picture by making sense of the individual events (Klein \& Myers, 1999). Our study thus facilitates a new understanding of entrepreneurial behavior by conducting a qualitative analysis, which can be employed to study historical events in a variety of contexts (Mumford, 2002).

\section{Method}

\section{Data}

The data for our study was derived from the film Pirates of Silicon Valley (PSV), which documents the emergence of the PC industry. A film is a "vivid text" that unfolds over time (Valdez \& Halley, 1999). Rudy, Popova, and Linz (2010) argue that films occupy an important position in contemporary society because they reflect social norms and conventions, as well as socialize people by communicating ideas about what is (or is not) acceptable in a particular society. Scholars studying the sociology of knowledge consider films to be very useful in establishing and maintaining norms, values, and beliefs in society (Freeman \& Valentine, 2004). Thus, films constitute "an important cultural text," especially in "a predominately visual culture, in which films are often watched far more readily" than other texts are consumed (Jasper, 2004: 128). Yet, as Neuendorf and others (2010: 759) note, "films are a body of media content that is often overlooked" by business organizational researchers. This is especially true in entrepreneurship research, where films remain unexplored as a data source for textual analysis (Gartner, 2010b).

PSV has several characteristics that make it suitable for this research (Eisenhardt \& Graebner, 2007). First, the film develops complex arguments, going beyond the usual storybook template of entrepreneurship stories. This atypicality lends credibility and authenticity to the story presented in the film, making it worthy of study (Ahl \& Czarniawska, 2010). Second, PSV presents an account of events during the PC industry's emergence that unfold over several years, linking antecedents to consequences through actions, and in specific contexts (Lunce \& Smith, 2005). It creates a meaningful account of industry emergence from disparate activities linking the industry's fragmented, messy, and non-linear history into a coherent whole (Fletcher, 2007), describing how the industry came about, and the problems and opportunities encountered along the way (Fletcher, 2007). Third, the film offers several well-researched entrepreneurial episodes that can be supplemented with additional research (Mumford, 2002). Although the story told in PSV is a retrospective account by Steve Wozniak (the co-founder of Apple) and Paul Allen (the co-founder of Microsoft), several notable individuals (e.g., Ed Roberts, Bill Gates, Steve Jobs, and Mike Marakula) and organizations (e.g., Xerox and IBM) that each played an important part in the nascent PC industry are also introduced, seen, and heard in the film.

\section{Research Methodology and Analysis}

Our methodological approach involved the identification of episodes of entrepreneurial behavior that could be analyzed to develop theoretical insights (Mumford, 2002). We (i.e., research team of two scientists and two research assistants) watched the film attentively (several times in full and in parts) to identify such episodes. Taking the theoretical tenets of discovery and creation into consideration (see Table 1), we deliberately selected episodes of entrepreneurial behavior that, in our view, illustrate the two theoretical frameworks dicussed above (Diesing, 1991). Our approach was consistent with theory-based sampling, which selects examples for their potential to manifest or elucidate chosen concepts (Neergaard, 2007). An initial intercoder reliably of $90 \%$ was achieved among the four team members before the eventual collection of entrepreneurial episodes was approved. These episodes covered a variety of entrepreneurial behaviors across a range of contexts and situations. Since all the selected episodes occurred over a specific time-span (the early 1970s to the mid-1980s) in a specific cultural setting (the US), our approach implicitly controlled for historical and cultural factors (Eisenhardt, 1989).

We identified five exemplary episodes each of discovery and creation. Some qualitative researchers have noted that understanding evolves when one moves "from the whole to the part and back to the whole" (Myers, 2009: 191). This suggests that the more cases a researcher examines and the more information obtained about each case, the better the 
understanding of the entrepreneurial phenomenon and its various aspects (Gartner, 2007). Neergaard (2007) compared such research to a jigsaw puzzle: by putting individual pieces together, a more holistic picture emerges. However, there are no decisive guidelines about how many episodes are needed to provide a complete understanding of any phenomenon. Eisenhardt and Bourgeois (1988) use four firms in their study of the microcomputer industry, while Mumford and van Doorn (2001) examine ten critical incidents from Benjamin Franklin's life.

Following prior research (Klein \& Meyers, 1999; Mumford, 2002), we pursued a multi-stage approach. We selected appropriate entrepreneurial episodes from the film, described the context in which these occur, interpreted the interrelationships between selected episodes and other parts of the film, as well as its overall context, and eventually interpreted the results beyond the original context. The interpretation and understanding of the ten selected episodes in their proper context was achieved by using a broad range of textual sources, including books and articles related to the PC industry. Our use of outside sources to understand the meaning of each scene is consistent with the notion that once a narrative has been produced as a work (i.e. textualized), it acquires a certain autonomy from its original production, as well as from the participants involved (Thompson, 1984), thus allowing for new interpretations (Tan, Wilson, \& Olver, 2009). In the words of Ricoeur (1981):

To interpret $[. .$.$] is to appropriate bere and now$ the intention of the text $[\ldots]$ the intended meaning of the text is not essentially the presumed intention of the author, the lived experience of the writer, but rather what the text means....

\section{Episodes and Findings}

Tables 2 and 3 present a summary of ten selected entrepreneurial episodes (five of discovery and five of creation) with regards to their film context, thematic substantiation, and industry relevance. We summarize each scene individually, provide a timeline to identify its occurrence in the film, and link it with events and incidents from the film and the real world. Unless referenced otherwise, all direct quotes in this section (including Tables 2 and 3) are from the film.

We use numbers ( 1 to 5$)$ to refer to specific discovery and creation scenes. For instance, "Paul Allen and Bill Gates discover the need for computer language" is referred to as discovery scene 1 , and "Apple I is built" is referred to as creation scene 1.

Table 2. Discovery Episodes from the film Pirates of Silicon Valley (PSV)

\begin{tabular}{|c|c|c|c|c|}
\hline \multicolumn{5}{|c|}{ Discovery Episodes } \\
\hline & Synopsis & Film Context & $\begin{array}{l}\text { Thematic Substantiation } \\
\text { (with regards to "discovery") }\end{array}$ & $\begin{array}{l}\text { Industry Relevance } \\
\text { (Literature Support) }\end{array}$ \\
\hline $\begin{array}{l}\text { Scene 1: } \\
\text { Paul Allen } \\
\text { and Bill } \\
\text { Gates discover } \\
\text { the need for a } \\
\text { computer } \\
\text { language } \\
\text { Film } \\
\text { timeline: } \\
\text { 10:25-12:17 }\end{array}$ & $\begin{array}{l}\text { Paul Allen spots a re- } \\
\text { cent issue of Popular } \\
\text { Electronics magazine } \\
\text { with a picture of the } \\
\text { Altair } 8800 \text { computer } \\
\text { on the cover. He } \\
\text { shows it to Bill Gates, } \\
\text { who realizes that the } \\
\text { Altair lacks a program- } \\
\text { ming language as } \\
\text { "right now it just sits } \\
\text { there and blinks." }\end{array}$ & $\begin{array}{l}\text { This scene takes place fairly } \\
\text { early on in the film. Allen } \\
\text { and Gates are Harvard stu- } \\
\text { dents. It is followed by } \\
\text { Gates's specific efforts to } \\
\text { gain direct contact with the } \\
\text { makers of the Altair (Ed } \\
\text { Roberts of Micro Instru- } \\
\text { mentation and Telemetry } \\
\text { Systems) to propose the } \\
\text { development of a computer } \\
\text { language. }\end{array}$ & $\begin{array}{l}\text { This scene shows that the initia- } \\
\text { tion of discovery occurring exog- } \\
\text { enously. Paul Allen's and Bill } \\
\text { Gates's prior knowledge and } \\
\text { interest in computers led them to } \\
\text { pursue an opportunity that was } \\
\text { there for everyone to grab. Paul } \\
\text { Allen "stumbles upon" the maga- } \\
\text { zine article about the Altair in a } \\
\text { typical Kirznerian fashion. He } \\
\text { was not searching for it; in fact, } \\
\text { he serendipitously comes across } \\
\text { the article, which informs him of } \\
\text { the Altair's development. The } \\
\text { magazine stated that there was a } \\
\text { demand for a suitable program- } \\
\text { ming language (Day, 1994). Paul } \\
\text { and Bill just needed to write a } \\
\text { language to meet this demand. }\end{array}$ & $\begin{array}{l}\text { The film indicates that these } \\
\text { events take place after } 1974 \text {. This } \\
\text { can be confirmed, as the Popular } \\
\text { Electronics magazine cover depict- } \\
\text { ing the Altair } 8800 \text { was published } \\
\text { in January } 1975 \text { (Karlgaard, } \\
\text { 2006). The Altair } 8800 \text { 's intro- } \\
\text { duction was an important chap- } \\
\text { ter in the computer industry's } \\
\text { history, as its build-it-yourself } \\
\text { design helped make small com- } \\
\text { puters available to a large con- } \\
\text { sumer (i.e. non-corporate) mar- } \\
\text { ket, which eventually led to the } \\
\text { development of the PC industry } \\
\text { (Hill \& Deeds, 1996). It is here } \\
\text { that Gates and Allen's interest in } \\
\text { computers is channeled into } \\
\text { (business) efforts for the first } \\
\text { time (i.e., the development of a } \\
\text { computer language). }\end{array}$ \\
\hline
\end{tabular}


Table 2. Discovery Episodes from the film Pirates of Silicon Valley (PSV) (continued)

\begin{tabular}{|c|c|c|c|c|}
\hline \multicolumn{5}{|c|}{ Discovery Episodes } \\
\hline & Synopsis & Film Context & $\begin{array}{l}\text { Thematic Substantiation } \\
\text { (with regards to "discovery") }\end{array}$ & $\begin{array}{l}\text { Industry Relevance } \\
\text { (Literature Support) }\end{array}$ \\
\hline $\begin{array}{l}\text { Scene 2: } \\
\text { Steve Jobs and } \\
\text { Steve Wozniak } \\
\text { discover a mar- } \\
\text { ket for personal } \\
\text { computers } \\
\text { Film } \\
\text { timeline: } \\
\text { 18:49-20:40 }\end{array}$ & $\begin{array}{l}\text { Steve Jobs and Steve } \\
\text { Wozniak present the } \\
\text { Apple I at the Home- } \\
\text { brew Computer Club } \\
\text { meeting in Berkeley. } \\
\text { They enter the venue } \\
\text { while the Altair } 8800 \text { is } \\
\text { being presented on } \\
\text { stage. At the meeting, } \\
\text { they set up their own } \\
\text { homemade computer. } \\
\text { The computer's design } \\
\text { impresses the audience } \\
\text { and makes Jobs and } \\
\text { Wozniak the center of } \\
\text { attention. They leave } \\
\text { the meeting with or- } \\
\text { ders for fifty comput- } \\
\text { ers. }\end{array}$ & $\begin{array}{l}\text { This scene is preceded by } \\
\text { scenes depicting the gen- } \\
\text { eral struggle of both Jobs } \\
\text { and Wozniak to find di- } \\
\text { rection in life. Up to this } \\
\text { point, they seemingly } \\
\text { have no clear aim or in- } \\
\text { tention behind their ac- } \\
\text { tions. The obvious suc- } \\
\text { cess of their prototype, } \\
\text { basically anticipating the } \\
\text { design of personal com- } \\
\text { puters to come, confirms } \\
\text { their initial "feel" for the } \\
\text { market and, most im- } \\
\text { portantly, indicates a clear } \\
\text { market potential. The } \\
\text { scene is followed by Jobs } \\
\text { sharing his ideas about } \\
\text { future prospects of their } \\
\text { endeavor with Wozniak. }\end{array}$ & $\begin{array}{l}\text { Primarily due to their alertness, } \\
\text { Jobs and Wozniak were able to } \\
\text { interpret the positive response to } \\
\text { their product as a clear indication } \\
\text { of a market opportunity. The } \\
\text { feedback from the audience is an } \\
\text { exogenous factor confirming } \\
\text { their discovery's potential value. } \\
\text { It demonstrates that Steve Jobs } \\
\text { and Steve Wozniak find an unmet } \\
\text { demand for small computers } \\
\text { among people who had previous- } \\
\text { ly not been considered computer } \\
\text { buyers (Bergin, 2006; Levy, 2007). } \\
\text { This demand was latent and not } \\
\text { explicit, as the major computer } \\
\text { companies of the day were appar- } \\
\text { ently not aware of it, and poten- } \\
\text { tial customers were not asking for } \\
\text { personal computers (Jackson, } \\
\text { Mandeville \& Potts, 2002). }\end{array}$ & $\begin{array}{l}\text { The recognition of the oppor- } \\
\text { tunity to sell personal computers } \\
\text { is a central event in the indus- } \\
\text { try's history (Holcombe, 1999). } \\
\text { The product they present is later } \\
\text { referred to as the Apple I. The } \\
\text { market success of the Apple I } \\
\text { was due to its most distinct fea- } \\
\text { ture: it was a fully assembled } \\
\text { machine with an input device } \\
\text { and an output device. }\end{array}$ \\
\hline $\begin{array}{l}\text { Scene 3: } \\
\text { Microsoft finds } \\
\text { DOS } \\
\text { Film } \\
\text { timeline: } \\
\text { 50:34-52:55 }\end{array}$ & $\begin{array}{l}\text { Microsoft needs oper- } \\
\text { ating software to sell } \\
\text { to IBM. The Seattle } \\
\text { Computer Company, } \\
\text { an independent ven- } \\
\text { ture, had developed an } \\
\text { operating system } \\
\text { known as QDOS } \\
\text { (Quick and Dirty Op- } \\
\text { erating System). After } \\
\text { some negotiations, } \\
\text { Microsoft buys the } \\
\text { QDOS for 50,000 } \\
\text { USD. }\end{array}$ & $\begin{array}{l}\text { Microsoft enters into a } \\
\text { deal to provide the Disk } \\
\text { Operating System (DOS), } \\
\text { a product that, at the } \\
\text { time, they knew they did } \\
\text { not yet have. } \\
\text { Microsoft adapts the } \\
\text { QDOS to IBM's require- } \\
\text { ments and licenses to } \\
\text { other companies. The } \\
\text { deal is a turning point in } \\
\text { Microsoft's development, } \\
\text { as it enabled it to become } \\
\text { an IMB business partner. }\end{array}$ & $\begin{array}{l}\text { Microsoft realized there was a } \\
\text { business opportunity if they } \\
\text { could obtain an operating system } \\
\text { someone else had actually devel- } \\
\text { oped without seeing its market } \\
\text { potential. Thus, based on its prior } \\
\text { knowledge and alertness to this } \\
\text { gap, Microsoft discovered a sig- } \\
\text { nificant opportunity, which es- } \\
\text { sentially involved arbitrage } \\
\text { (Loasby, 1992). As Kirzner (1973: } \\
\text { 79) explained, an arbitrageur- } \\
\text { entrepreneur "sells for high prices } \\
\text { that which he can buy for low } \\
\text { prices." The arbitrageur helps } \\
\text { close pockets of ignorance in the } \\
\text { market by acquiring a bundle of } \\
\text { rights to attributes (i.e. a distinct } \\
\text { asset) in one transaction and sell- } \\
\text { ing the asset in another transac- } \\
\text { tion (Foss, Foss, Klein, \& Klein, } \\
\text { 2007). }\end{array}$ & $\begin{array}{l}\text { The episode supposedly takes } \\
\text { place in 1980, after Steve } \\
\text { Ballmer had joined Microsoft } \\
\text { and when IBM required an op- } \\
\text { erating system for its microcom- } \\
\text { puters (Jackson, Mandeville, \& } \\
\text { Potts, 2002). Not having devel- } \\
\text { oped anything close to what } \\
\text { IBM was asking them for, they } \\
\text { acquired what was known as } \\
\text { QDOS (Wallace, 1993). }\end{array}$ \\
\hline
\end{tabular}


Table 2. Discovery Episodes from the film Pirates of Silicon Valley (PSV) (continued)

\begin{tabular}{|c|c|c|c|c|}
\hline \multicolumn{5}{|c|}{ Discovery Episodes } \\
\hline \multicolumn{2}{|c|}{ Synopsis } & Film Context & $\begin{array}{l}\text { Thematic Substantiation } \\
\text { (with regards to "discovery") }\end{array}$ & $\begin{array}{l}\text { Industry Relevance } \\
\text { (Literature Support) }\end{array}$ \\
\hline $\begin{array}{l}\text { Scene 4: } \\
\text { Apple discovers } \\
\text { WIMP } \\
\text { Film } \\
\text { timeline: } \\
\text { 1:00:51-1:03:53 }\end{array}$ & $\begin{array}{l}\text { A team from Apple } \\
\text { visits the Xerox Palo } \\
\text { Alto Research Cen- } \\
\text { ter. Apple has } \\
\text { learned that Xerox } \\
\text { has been developing } \\
\text { new, advanced tech- } \\
\text { nological applica- } \\
\text { tions such as the } \\
\text { computer mouse and } \\
\text { graphical user inter- } \\
\text { face. Xerox corpo- } \\
\text { rate office does not } \\
\text { consider these inno- } \\
\text { vations relevant to } \\
\text { their business, so } \\
\text { they allow Apple to } \\
\text { study them in detail. } \\
\text { The technological } \\
\text { development at Xer- } \\
\text { ox surprises the Ap- } \\
\text { ple team, which pro- } \\
\text { ceeds to adapt these } \\
\text { innovations for their } \\
\text { own purposes. }\end{array}$ & $\begin{array}{l}\text { This scene follows Steve } \\
\text { Jobs echoing Picasso's fa- } \\
\text { mous words: "Good artists } \\
\text { copy. Great artists steal." } \\
\text { Jobs makes this idea the } \\
\text { guiding philosophy by } \\
\text { which Apple conducted its } \\
\text { business. Viewer attention } \\
\text { is then drawn to Xerox's } \\
\text { innovations. } \\
\text { The scene is followed by a } \\
\text { voice-over from Wozniak } \\
\text { concluding that with } \\
\text { "about } 100 \text { billion USD } \\
\text { head-start on anyone else, } \\
\text { Apple was making tons of } \\
\text { money." }\end{array}$ & $\begin{array}{l}\text { Apple clearly realized the huge } \\
\text { potential of these inventions and } \\
\text { their impact on personal com- } \\
\text { puters' design and capabilities, } \\
\text { while the top management at } \\
\text { Xerox did not see much poten- } \\
\text { tial in these products } \\
\text { (Holcombe, 1999; Shane, 2000). } \\
\text { Based on their prior knowledge } \\
\text { of and experience in the com- } \\
\text { puter industry, Apple realized } \\
\text { that there was an opportunity to } \\
\text { obtain these technologies from } \\
\text { Xerox. As Shane (2000) notes, } \\
\text { prior knowledge "from work } \\
\text { experience, education, or other } \\
\text { means, influences the entrepre- } \\
\text { neur's ability to comprehend, } \\
\text { extrapolate, interpret, and apply } \\
\text { new information in ways that } \\
\text { those lacking that prior infor- } \\
\text { mation cannot replicate." }\end{array}$ & $\begin{array}{l}\text { This scene supposedly takes place } \\
\text { in December 1979, when Xerox } \\
\text { indeed granted Apple three days' } \\
\text { access to familiarize themselves } \\
\text { with their Palo Alto Research } \\
\text { Center (Levy, 1994; Wozniak \& } \\
\text { Smith, 2006). Although Xerox } \\
\text { received pre-IPO shares from Ap- } \\
\text { ple for this privilege, the techno- } \\
\text { logical advantage Xerox was giv- } \\
\text { ing away here was significant. In } \\
\text { Levy's words (1994: 77-78), "the } \\
\text { number crunchers at Xerox con- } \\
\text { sidered this a fairly innocuous } \\
\text { concession-they were getting a } \\
\text { tangible stock deal in exchange } \\
\text { for allowing Apple a brief expo- } \\
\text { sure to technology that in their } \\
\text { minds belonged more to science } \\
\text { fiction than to future revenues." } \\
\text { It ultimately led to the develop- } \\
\text { ment of the Apple Lisa with a } \\
\text { graphical user interface (Wozniak } \\
\text { \& Smith, 2006). }\end{array}$ \\
\hline $\begin{array}{l}\text { Scene 5: } \\
\text { Gates discovers } \\
\text { the graphical user } \\
\text { interface } \\
\text { Film } \\
\text { timeline: } \\
\text { 1:04:54-1:07:21 }\end{array}$ & $\begin{array}{l}\text { When Bill Gates } \\
\text { discovers the graph- } \\
\text { ical user interface, he } \\
\text { becomes concerned } \\
\text { about Apple's tech- } \\
\text { nological head start. } \\
\text { He is eager to join } \\
\text { forces with Apple. } \\
\text { He is able to con- } \\
\text { vince the initially } \\
\text { indifferent Jobs to } \\
\text { trust him (personally) } \\
\text { and to provide him } \\
\text { with prototypes of } \\
\text { the Macintosh long } \\
\text { before its introduc- } \\
\text { tion to the market. }\end{array}$ & $\begin{array}{l}\text { In the film, this specific } \\
\text { scene starts by showing Bill } \\
\text { Gates trying an Apple com- } \\
\text { puter in his office. Having } \\
\text { met with Steve Jobs, direct- } \\
\text { ly after leaving the building, } \\
\text { Gates mentions to Ballmer } \\
\text { "if he [Jobs] is not careful, } \\
\text { he is going to wreck the } \\
\text { place," thus making no } \\
\text { secret of his plans to copy } \\
\text { Apple's innovations for } \\
\text { himself. This scene recalls } \\
\text { Apple adapting Xerox's } \\
\text { innovations (Scene 4), with } \\
\text { the major difference that } \\
\text { Jobs is not aware of Gates's } \\
\text { plans. }\end{array}$ & $\begin{array}{l}\text { Gates becomes aware that Ap- } \\
\text { ple, with its progressive corpo- } \\
\text { rate culture and technological } \\
\text { lead, is the real competitor in the } \\
\text { market. At a time when Jobs still } \\
\text { perceived IBM as the major } \\
\text { threat, Microsoft and Apple have } \\
\text { actually become direct rivals. } \\
\text { This opens the opportunity for } \\
\text { Gates to gain Jobs's trust and to } \\
\text { adapt their innovations before } \\
\text { Jobs realizes what is happening. } \\
\text { Alertness to opportunities and } \\
\text { knowledge of market potential } \\
\text { are the basis of Gates's discov- } \\
\text { ery. }\end{array}$ & $\begin{array}{l}\text { This scene presumably takes } \\
\text { place in } 1983 \text { (Wozniak \& Smith, } \\
\text { 2006; Simmons, 2007). It depicts } \\
\text { an important moment in the } \\
\text { development of the relationship } \\
\text { between Apple and Microsoft, as } \\
\text { well as between Jobs and Gates, } \\
\text { because it lays the foundation of } \\
\text { the direct competition between } \\
\text { the two companies, which con- } \\
\text { tinues to this day (Wallace, } \\
\text { 1993). } \\
\text { Notably, at this time, Bill Gates } \\
\text { was not actively searching for } \\
\text { new technologies for operating } \\
\text { software. Microsoft had already } \\
\text { gained a reputation in operating } \\
\text { systems and programming lan- } \\
\text { guages (Rivlin, 1999). When } \\
\text { Gates saw the graphical user } \\
\text { interface developed at Apple, he } \\
\text { "knew [it] portended the fu- } \\
\text { ture" (Levy, 1994: 161). Mi- } \\
\text { crosoft then zealously turned its } \\
\text { attention to working on this new } \\
\text { software, which formed the basis } \\
\text { of its now ubiquitous Windows } \\
\text { product (Holcombe, 2003). }\end{array}$ \\
\hline
\end{tabular}


Table 3. Creation Episodes from the film Pirates of Silicon Valley (PSV)

\begin{tabular}{|c|c|c|c|c|}
\hline \multicolumn{5}{|c|}{ Creation Episodes } \\
\hline \multicolumn{2}{|c|}{ Synopsis } & Film Context & $\begin{array}{l}\text { Thematic Substantiation } \\
\text { (with regards to "creation") }\end{array}$ & $\begin{array}{l}\text { Industry Relevance } \\
\text { (Literature Support) }\end{array}$ \\
\hline $\begin{array}{l}\text { Scene 1: } \\
\text { Apple I is built } \\
\text { Film } \\
\text { Timeline: } \\
\text { 16:09-18:02 }\end{array}$ & $\begin{array}{l}\text { Wozniak and Jobs, } \\
\text { university students at } \\
\text { the time, are at the } \\
\text { kitchen table, chat- } \\
\text { ting and working on } \\
\text { constructing a com- } \\
\text { puter (which later } \\
\text { came to be called the } \\
\text { Apple I). From their } \\
\text { conversation, it be- } \\
\text { comes apparent that, } \\
\text { so far, also with re- } \\
\text { gard to the computer } \\
\text { on which they are } \\
\text { working, they have } \\
\text { no clear goal, not to } \\
\text { mention business } \\
\text { intentions. }\end{array}$ & $\begin{array}{l}\text { The actual scene does not } \\
\text { depict the specific proce- } \\
\text { dure by which the computer } \\
\text { is built. Yet, the characters' } \\
\text { comments and work make it } \\
\text { clear that they are building a } \\
\text { computer. For example, a } \\
\text { reporter from the Mercury } \\
\text { News wants to interview } \\
\text { Wozniak when he learns } \\
\text { that they are building a com- } \\
\text { puter "all from spare parts." }\end{array}$ & $\begin{array}{l}\text { The construction of the Apple I } \\
\text { computer was not based on an } \\
\text { existing design; instead, it in- } \\
\text { volved imagination, tinkering, and } \\
\text { trial and error, with several set- } \\
\text { backs along the way (see Table 1). } \\
\text { According to Levi-Strauss (1967), } \\
\text { entrepreneurship often involves } \\
\text { making do with "whatever is at } \\
\text { hand." The conscious and willful } \\
\text { tendency to make do also in- } \\
\text { volves combining and re-using } \\
\text { existing resources to put them to } \\
\text { unexpected uses, sometimes re- } \\
\text { sulting in "brilliant unforeseen } \\
\text { results" (Baker \& Nelson, 2005). } \\
\text { The willingness to make do and } \\
\text { engage in resource recombination } \\
\text { facilitated the construction of the } \\
\text { Apple I by two young men with } \\
\text { very limited resources and no } \\
\text { existing blueprint to follow in } \\
\text { terms of what a computer should } \\
\text { look like. }\end{array}$ & $\begin{array}{l}\text { From the film, no clear de- } \\
\text { duction can be made regard- } \\
\text { ing the period during which } \\
\text { the construction of the Apple } \\
\text { I took place. But there can be } \\
\text { little doubt that design was a } \\
\text { milestone in the development } \\
\text { of the PC industry (Moritz, } \\
\text { 1984). The homemade com- } \\
\text { puter was built from parts } \\
\text { that were readily available; } \\
\text { yet, the finished product } \\
\text { turned out to be the first per- } \\
\text { sonal computer that provided } \\
\text { a realistic marketing oppor- } \\
\text { tunity (Wozniak \& Smith, } \\
\text { 2006). The Apple I's signifi- } \\
\text { cance also lies in it serving as } \\
\text { a model for future genera- } \\
\text { tions of computers, as subse- } \\
\text { quent computers were ex- } \\
\text { pected to have a keyboard to } \\
\text { enter information and a mon- } \\
\text { itor to display output. }\end{array}$ \\
\hline $\begin{array}{l}\text { Scene 2: } \\
\text { Apple is founded } \\
\text { in a garage } \\
\text { Movie } \\
\text { Timeline: } \\
\text { 20:40-23:04 }\end{array}$ & $\begin{array}{l}\text { Jobs and Wozniak } \\
\text { start to build their } \\
\text { computers in Jobs's } \\
\text { parents' garage. They } \\
\text { have little funds. It is } \\
\text { also not clear at this } \\
\text { point whether } \\
\text { Hewlett-Packard } \\
\text { (HP) actually has } \\
\text { ownership of Woz- } \\
\text { niak's computer de- } \\
\text { sign, as he works for } \\
\text { them, and has signed } \\
\text { a contract. When HP } \\
\text { management scoffs at } \\
\text { the idea of computers } \\
\text { for everyday use, } \\
\text { Steve Jobs and Woz- } \\
\text { niak start their com- } \\
\text { pany, calling it Apple } \\
\text { Computers. }\end{array}$ & $\begin{array}{l}\text { This scene follows the suc- } \\
\text { cessful presentation of the } \\
\text { Apple I at the Homebrew } \\
\text { Computer Club in } 1976 . \\
\text { The interest they saw among } \\
\text { people for their design con- } \\
\text { vinced Jobs and Wozniak to } \\
\text { go ahead and build comput- } \\
\text { ers in larger numbers to sell } \\
\text { to individual customers. The } \\
\text { scene is followed by another } \\
\text { scene, which shows Steve } \\
\text { Jobs trying to secure a bank } \\
\text { loan to finance the busi- } \\
\text { ness's initial expansion, a } \\
\text { task at which he is not suc- } \\
\text { cessful at first. }\end{array}$ & $\begin{array}{l}\text { The formation of a new organiza- } \\
\text { tion is arguably the most im- } \\
\text { portant aspect of entrepreneurial } \\
\text { activity (Gartner, 1990). Apple } \\
\text { was founded when PCs were an } \\
\text { untested idea, and it was not clear } \\
\text { why "ordinary people would want } \\
\text { computers." Starting the compa- } \\
\text { ny under such circumstances in- } \\
\text { volved imaginative entrepreneurs' } \\
\text { intentionality (to sell computers), } \\
\text { acquisition of resources (e.g., } \\
\text { obtaining credit from suppliers), } \\
\text { taking an organizational identity } \\
\text { (the name Apple Computers), and } \\
\text { transacting with customers as a } \\
\text { business (Katz \& Gartner, 1988). }\end{array}$ & $\begin{array}{l}\text { Organizing disparate business } \\
\text { activities and selling comput- } \\
\text { ers into a formal business was } \\
\text { obviously key to Apple's } \\
\text { commercial success (Wozniak } \\
\text { \& Smith, 2006). If the various } \\
\text { activities had not been orga- } \\
\text { nized into a business, it } \\
\text { would have been impossible } \\
\text { to create the necessary mo- } \\
\text { mentum and legitimacy for } \\
\text { the new venture. As the Woz- } \\
\text { niak character explains in the } \\
\text { film, this was a time when } \\
\text { "business guys and bankers } \\
\text { thought you had just barfed } \\
\text { on their shoes if you tried to } \\
\text { interest them into computers } \\
\text { for ordinary people." Apple } \\
\text { soon becomes the world's } \\
\text { leading personal computer } \\
\text { company (Levy, 1994), and in } \\
\text { less than five years after its } \\
\text { founding, Apple enters the } \\
\text { Fortune } 500 \text { list. }\end{array}$ \\
\hline
\end{tabular}


Table 3. Creation Episodes from the film Pirates of Silicon Valley (PSV) (continued)

\begin{tabular}{|c|c|c|c|c|}
\hline \multicolumn{5}{|c|}{ Creation Episodes } \\
\hline \multicolumn{2}{|c|}{ Synopsis } & Film Context & $\begin{array}{l}\text { Thematic Substantiation } \\
\text { (with regards to "creation") }\end{array}$ & $\begin{array}{l}\text { Industry Relevance } \\
\text { (Literature Support) }\end{array}$ \\
\hline $\begin{array}{l}\text { Scene 3: } \\
\text { Creation of the } \\
\text { software business } \\
\text { Movie } \\
\text { Timeline: } \\
\text { 48:02-50:30 }\end{array}$ & $\begin{array}{l}\text { Bill Gates, Paul Al- } \\
\text { len, and Steve } \\
\text { Ballmer visit IBM } \\
\text { headquarters. They } \\
\text { offer to license IBM } \\
\text { an operating system } \\
\text { for their new line of } \\
\text { computers to com- } \\
\text { pete with Apple. } \\
\text { IBM finds their sug- } \\
\text { gestion "no big } \\
\text { deal"-- "the profits } \\
\text { are in the computers } \\
\text { themselves, not this } \\
\text { software stuff" is } \\
\text { how an IBM manag- } \\
\text { er put it. }\end{array}$ & $\begin{array}{l}\text { At the time that Microsoft } \\
\text { dares to propose this deal } \\
\text { to IBM, the company has } \\
\text { had only limited market } \\
\text { success. In the words of } \\
\text { Steve Ballmer, at this stage, } \\
\text { the company is still a "two- } \\
\text { bit little outfit." From this } \\
\text { vulnerable position, they } \\
\text { sought to create a new } \\
\text { business, in which Mi- } \\
\text { crosoft would retain owner- } \\
\text { ship of the software and } \\
\text { customers would only ob- } \\
\text { tained usage rights. }\end{array}$ & $\begin{array}{l}\text { Microsoft succeeded in carving } \\
\text { out an entirely new software } \\
\text { business market in an era when } \\
\text { the established wisdom was that } \\
\text { the profitable side of computers } \\
\text { is hardware, not software. This } \\
\text { required imagination and conjec- } \\
\text { ture based on future expecta- } \\
\text { tions. We consider Microsoft's } \\
\text { exploitation of a perceived op- } \\
\text { portunity in software as an entre- } \\
\text { preneurial creation episode, as it } \\
\text { led to the unforeseen emergence } \\
\text { of an entirely new industry. By } \\
\text { choosing to walk an unbeaten } \\
\text { path, Microsoft was taking a } \\
\text { massive risk (Aldrich \& Fiol, } \\
\text { 1994). }\end{array}$ & $\begin{array}{l}\text { Around 1980, IBM decided to } \\
\text { take on the challenge Apple pre- } \\
\text { sented in the PC market. It re- } \\
\text { quired an operating system for } \\
\text { its machines (Jackson, Mande- } \\
\text { ville, \& Potts, 2002). Microsoft } \\
\text { saw the opportunity and the } \\
\text { market value in the software, as } \\
\text { opposed to the IBM's emphasis } \\
\text { on the hardware. Within four } \\
\text { years of the "breakthrough deal" } \\
\text { with IBM, TIME magazine fea- } \\
\text { tured the 28-year-old Bill Gates } \\
\text { on its cover, calling software } \\
\text { "the magic carpet to the future" } \\
\text { and the "soul of the [computer] } \\
\text { machine" (Taylor, Moritz, \& } \\
\text { Stoler, 1984). }\end{array}$ \\
\hline $\begin{array}{l}\text { Scene 4: } \\
\text { Xerox invents } \\
\text { the mouse and } \\
\text { GUI } \\
\text { Film } \\
\text { Timeline: } \\
\text { 1:01:04-1:01:48 }\end{array}$ & $\begin{array}{l}\text { In the words of a } \\
\text { Xerox executive, } \\
\text { "We created the } \\
\text { mouse and all the } \\
\text { rest of } \\
\text { it..." (1:02:30). }\end{array}$ & $\begin{array}{l}\text { This scene is presented in } \\
\text { the film after Wozniak has } \\
\text { shared that "Xerox was } \\
\text { secretly developing all this } \\
\text { amazing stuff like the } \\
\text { mouse and the graphics on } \\
\text { the screen, instead of a } \\
\text { bunch of numbers." It is } \\
\text { followed by Wozniak com- } \\
\text { paring the development at } \\
\text { Xerox to a Rembrandt, } \\
\text { worth about "a hundred } \\
\text { billion dollars." }\end{array}$ & $\begin{array}{l}\text { The mouse invented at Xerox } \\
\text { was a palm-sized contraption } \\
\text { that contained a metal ball } \\
\text { pressed against two rollers to } \\
\text { track movement and send digital } \\
\text { positional information directly to } \\
\text { the computer. Although it was } \\
\text { not the first mouse invented (the } \\
\text { credit for that goes to Doug } \\
\text { Engelbart at Stanford Research } \\
\text { Institute) (Levy, 1994), it provid- } \\
\text { ed the predominant model for } \\
\text { use in PC for years to come. We } \\
\text { consider Xerox's invention of } \\
\text { the mouse as a creation episode, } \\
\text { because it clearly illustrates imag- } \\
\text { ination translated into reality } \\
\text { through action based on future } \\
\text { expectations. }\end{array}$ & $\begin{array}{l}\text { It is not possible to assign an } \\
\text { accurate date or even timeframe } \\
\text { to this innovation process. How- } \\
\text { ever, the impact that the devel- } \\
\text { opment of the computer mouse } \\
\text { and graphical user interface has } \\
\text { generated for everyday compu- } \\
\text { ting today is significant: Both } \\
\text { tools are key interfaces for mod- } \\
\text { ern information technology. Fur- } \\
\text { thermore, with regards to this } \\
\text { film, and related industry rele- } \\
\text { vance, subsequent work at Apple } \\
\text { and developments in the com- } \\
\text { puter industry substantially built } \\
\text { on the mouse and the GUI } \\
\text { (Wozniak \& Smith, 2006). }\end{array}$ \\
\hline $\begin{array}{l}\text { Scene 5: } \\
\text { Apple creates the } \\
\text { Macintosh } \\
\text { Movie } \\
\text { Timeline: } \\
\text { 1:07:21-1:10:16 }\end{array}$ & $\begin{array}{l}\text { This scene presents } \\
\text { Steve Jobs as saying: } \\
\text { "Let me show you } \\
\text { the future... the } \\
\text { ultimate, insanely } \\
\text { great, fusion of art } \\
\text { and science... It's } \\
\text { called the Macin- } \\
\text { tosh." }\end{array}$ & $\begin{array}{l}\text { This scene is preceded by } \\
\text { the depiction of Apple as a } \\
\text { company that proudly dis- } \\
\text { played its pirate parapher- } \\
\text { nalia, and where employees } \\
\text { were expected to work 90- } \\
\text { hour weeks on a regular } \\
\text { basis. It is followed by } \\
\text { Wozniak recounting that, at } \\
\text { this time, "Apple was tear- } \\
\text { ing itself to pieces... the } \\
\text { Macintosh group against } \\
\text { everyone else in the compa- } \\
\text { ny." }\end{array}$ & $\begin{array}{l}\text { It becomes clear from the film } \\
\text { that the team, led by Steve Jobs, } \\
\text { has created a game-changer } \\
\text { through their actions, based on } \\
\text { their vision of the future, and } \\
\text { using their imagination. The } \\
\text { Macintosh's long-term impact on } \\
\text { future designs demonstrates its } \\
\text { disequilibrating effect on the } \\
\text { industry as a whole. }\end{array}$ & $\begin{array}{l}\text { The Macintosh was hailed by } \\
\text { fans as the "most revolutionary } \\
\text { introduction in the history of } \\
\text { personal computing." Although } \\
\text { it was fourth in the Apple series } \\
\text { of computers (preceded by Ap- } \\
\text { ple I, II, and Lisa), it was widely } \\
\text { regarded as "the computer that } \\
\text { changed everything." }\end{array}$ \\
\hline
\end{tabular}


As explained earlier, these scenes were selected for their potential to illustrate either discovery or creation, and demonstrated high inter-coder reliability when they were classified into discovery or creation categories. Tables 2 and 3 provide more context, which is an important result of our analysis, as the following is only summarized descriptions of our findings.

In discovery scene 1, Paul Allen spots the Altair 8800 computer developed by Micro Instrumentation and Telemetry Systems (MITS) on the cover of the "Popular Electronics" magazine, which he brings to Bill Gates's attention. This appears to be a classic example of entrepreneurial alertness as Allen "stumbles upon" the opportunity that exists "out there" through an exogenous event (Kirzner, 1997). Yet, when related scenes, as well as the overall film context are taken into consideration, it becomes obvious that simply finding the Altair 8800 on a magazine cover was not enough. It took Gates and Allen's proactive action to convince Ed Roberts of their offer to provide a programming language for the Altair, which facilitated their entry into the industry and the start of Microsoft. As Gates (2010) recounted recently, "Ed [took] a chance on us-two young guys interested in computers-and [when] our first untested software worked on his Altair [it] was the start of a lot of great things."

In discovery scene 2, Jobs and Wozniak arrive at a meeting of the Homebrew Computer Club at Stanford. The club was "where a bunch of guys spent all their spare time trying to ... show the stuff they built, except that most of it didn't really work all that well." They use the meeting to present their prototype of a personal computer, which results in sales to the club members. We categorize the recognition of the opportunity to sell personal computers as a discovery episode because Jobs and Wozniak find an unmet demand for small computers among common people, who had not been considered by large corporations as serious buyers earlier.

However, from creation scenes 1 and 2 it becomes obvious that the demand only surfaced after they had presented a working prototype of the computer they had built. We consider the building of the computer a creation episode (creation scene 1 in Table 3), although the movie tells us little about the detailed action taken to create the computer. The scene is rather implicitly presented but clearly indicates path-dependent behavior enacted by the two leading individuals behind Apple. Discovery scene 2 is preceded by creation scene 1 and followed by creation scene 2 when "Apple Computers" is started in a garage. More explicitly, creation scene 2 describes Apple's humble start with limited finances and unclear ownership structure. While this clearly outlines evolutionary behavior under uncertainty driven by the actors' imagination, it also foreshadows a disequilibriating outcome (see Table 1).

In discovery scene 3, Microsoft is asked to provide an operating system-foundation software that allocates storage and schedules tasks in a computer-for a new line of IBM personal computers. Microsoft finds that the Seattle Computer Company has developed an operating system known as QDOS (Quick and Dirty Operating System). Without disclosing its intention to re-sell the QDOS to IBM, Microsoft buys it from the Seattle Computer Company for $\$ 50,000$. Microsoft then adapts QDOS for use by IBM. We categorize this episode as discovery because it essentially involves arbitrage (Loasby, 1992). Such transactions comprise both demand and supply (Sarasvathy, Dew, Velamuri, \& Venkataraman, 2003). As is seen in this episode, there is both demand for and supply of disk operation system (DOS). Microsoft's role was to buy at a low price and sell at a high price, with the profit as the reward for this arbitrage.

In creation scene 3 , rather than sell the software outright to IBM as discovery theories predict, Microsoft negotiates the right to retain the ownership of the software. In effect, IBM obtained a license for the software from Microsoft, which was then free to also sell it to other computer manufacturers. We consider this a creation episode because at the time IBM believed that "the money is in hardware," while Microsoft expected software to become important. Microsoft's decision, which was based on certain expectations of the future, led to the unforeseen emergence of an entirely new industry. The deal between Microsoft and IBM can be readily traced to IBM being in dire need of an operating system and the Seattle Computer Company's development of the disc operating system, which Microsoft bought.

In discovery scene 4, a team from Apple visits Xerox's Palo Alto Research Center (PARC) for a preview of their latest research. The Apple team is shown the new technologies PARC is developingwindows, icons, a menu, and a pointing device (WIMP). These technological wonders amaze the Apple team, who ask probing questions about the different tools. By the end of the visit, the Apple team has "about a hundred billion dollar head-start over everyone else" in the computer business. We categorize this episode as discovery because it involves the Apple team seeing different value in the WIMP tools than the Xerox corporate managers, who had already been briefed on the technological developments in their research laboratory (Shane, 2000). 
Nevertheless, creation scene 4 clarifies that this discovery would not have occurred had Xerox not invented the WIMP technology in the first place. At the time of its development at Xerox, WIMP's usefulness was unclear and it seemed to belong "more to science fiction than to future revenues" (Levy, 1994: 78). In short time, the Xerox preview proved to be the "bedrock" on which the computer industry was constructed; a future in which Apple went on to become a leading player, while Xerox was relegated to a footnote.

In discovery scene 5, Microsoft learns that Apple is incorporating GUI into their computers, which is radically ahead of the command-line system in which Microsoft had been investing (Levy, 1994). Microsoft recognizes the usefulness of GUI and decides to incorporate the user interface in the now ubiquitous Windows product (Holcombe, 2003). We consider this a discovery episode as it involved Microsoft recognizing the potential value of a system that was already being developed by Apple. At this time, Microsoft was not actively searching for new technologies to use in their operating software, as the company had already gained somewhat of a reputation for its existing product line.

Nonetheless, in relation to creation scene 5 , one can see that Microsoft made a radical about-turn regarding the technology underlying its earlier software. It "just copied the Mac" in giving the new Windows software its look and feel (Jobs, 2005). We associate the Macintosh computer's construction with creation because it redefined the trajectory of the computer industry, setting the whole industry on a new path. According to Chan (2004), the Macintosh was "the most revolutionary introduction in the history of personal computing." The features that made the Macintosh "insanely great" were not, however, incorporated in response to consumer demands or market feedback, but reflected Apple's proactive initiative to "transform the world" and "put a dent in the Universe" (Levy, 1994: 6).

In the next section, we discuss various implications of the findings reported here. Although these findings are derived from an analysis of a specific industry context (i.e. the PC industry), we believe they have broader implications for entrepreneurship theory and practice, a topic to which we now turn our attention.

\section{Discussion}

The formative phase of a new industry is, in Utterback and Suarez's words (1993: 17), "predominantly entrepreneurial," making it worthy of closer study to understand entrepreneurial behavior. Our researchusing a novel qualitative method- revealed three key unanticipated findings. First, we found that that discovery and creation are fundamentally interrelated. Second, at least, during industry emergence, discovery and creation behaviors share a common element: bricolage. Third, we also found that ideological activism is a major component of entrepreneurial behavior in a new industry's formative years, as entrepreneurs seek to convince others of the value of their offerings and evangelize them into a new industry. We discuss each of these major findings of our study in greater detail below.

\section{Implications for Theory}

Our findings about the nature of entrepreneurial activity during industry emergence have important implications for theory development in entrepreneurship.

We find evidence of ideologically motivated behavior's role in discovery and creation in the emergent PC industry. We believe our finding is doubly informative. First, it reveals that during industry emergence, both discovery and creation activities involve enterprising actors engaging in evangelical efforts to make the new offering comprehensible and acceptable to others. The role of evangelism- or ideological activism- rather than economic maximization, has been previously recognized in the successful emergence of new industries such as automobiles (Rao, 2004) and wind energy (Sine \& Lee, 2009). However, these studies attribute evangelical efforts mostly to third-party organizations such as consumer clubs and social organizations (Lee, Sine, \& Tolbert, 2011). Our research reveals that enterprising actors occupy a vanguard position in advocacy efforts with ideological-rather than economic-motivation driving them to engage in entrepreneurial behavior. To our knowledge, such evangelism has not received any attention in the discovery and creation literature, which we hope will begin to be redressed as a consequence of our findings. Second, our conception of evangelism is consistent with the previously recognized influence of so-called champions who "energize efforts toward collective action and devise strategies... to create entirely new industries and associated institutions" which is at the heart of the growing institutional entrepreneurship literature (Garud, Jain, \& Kumaraswamy, 2002: 197-8). Notably, our findings extend this understanding of championing behavior in a new direction: Where evangelists have traditionally been believed to occupy "positions associated with the highest degrees of legitimacy," our research shows that activism is a key aspect of emerging industries even when the champions engaging in evangelizing efforts are themselves striving to gain legitimacy (Maguire, Hardy, \& Lawrence, 2004: 667). 
We also found that bricolage comprised a major part of both discovery and creation. This is a novel finding because bricolage has traditionally been associated only with creation approaches (Garud \& Karnoe, 2003). As the film reveals, bricolage helped nascent entrepreneurs - at Apple and Microsoftcounter their resource deficit by combining the resources around them. For example, the building of Apple I computer involved recombining readily available parts, and the founding of Apple involved obtaining parts on credit from a supplier and converting Jobs' parents' garage into a production floor and an office. Particularly interesting in the PSV context is that in the new industry's very early days, bricolage was dominant, while formulaic agency occurred much later (after venture creation) (Katz \& Gartner, 1988). Furthermore, we find evidence that bricolage also plays an important role in the discovery perspective. Contrary to the notion that discovery involves simply fulfilling predetermined resource requirements (Edelman \& Yli-Renko, 2010), we find evidence of bricolage in several discovery episodes, such as the discovery of a market for personal computers and Microsoft's discovery of DOS. Specifically, these episodes involve "network bricolage": the use of pre-existing contact networks to achieve objectives and goals (Baker, 2007). Research on bricolage only began in earnest in recent years. Based on our findings, we call for further research to gain a deeper understanding of bricolage's role in both discovery and creation.

Finally, our research reveals that discovery and creation behaviors are fundamentally interrelated, rather than simply competing (Edelman \& Yli-Renko, 2010) or complementary (Zahra, 2008). Creation behaviors generate new artifacts that enterprising actors discover over time yield more new artifacts, which become the basis for future creative endeavors. The intersection of discovery and creation thus moves the entrepreneurial process forward. We therefore suggest that, rather than polarize entrepreneurial phenomena by theorizing, researchers need to encompass both discovery and creation to build "constructs that accommodate contradictions" (Lewis, 2000: 773). Consideration of the interactive nature of discovery and creation may not find favor with either discovery or creation purists who tend to be dismissive of those on the other side of aisle. Yet, our findings suggest that comprehensive understanding of industry emergence requires combining insights from both perspectives. In a similar vein, Evans and Doz (1992) argue that the duality concept offers a new provocative framework for exploring complex phenomena such as entrepreneurship. Within a duality framework, researchers and scholars can explore questions related to the kinds of tensions that exist between discovery and creation, why the two might trigger reinforcing cycles, and how entrepreneurial agents can navigate through the two as catalysts for ongoing entrepreneurial behaviors (Graetz \& Smith, 2007). Thus, based on the findings of our study, future research would do well to consider the interactive nature of creation and discovery from the outset.

\section{Implications for Practice}

Our research also has certain implications for entrepreneurs. First, there is growing interest worldwide in practically relevant entrepreneurship research (Busenitz et al., 2003; Corner and Pavlovich, 2007). Entrepreneurship researchers are often encouraged to use entrepreneurship practice to inform their research; consequently, practice shapes research from the very onset. De'Tienne and Chandler (2004) note that studying real-world entrepreneurial activity, focusing specifically on issues related to actions and processes, will make entrepreneurship research more engaging. Corley and Gioia (2011) argue that researchers in management schools should conduct studies that provide business insights derived from real-world observations. This may specifically apply to entrepreneurship researchers, who are often called to and tasked with enhancing entrepreneurial activity in society. By seeking to understand behaviors of some of the most enterprising actors during one of the most entrepreneurial periods in recent US history, our research engages closely with entrepreneurship in a real-world context.

Second, prior research and anecdotal evidence indicate that nascent entrepreneurs are often advised to not disclose information about their activities to others. However, we find that even when entrepreneurs share their ideas and clearly describe what they are considering, others may not appreciate its potential. For example, Steve Wozniak was required to tell Hewlett Packard's (HP) management about his work on the new computer, but HP saw no future in activities related to designing and making a computer for individual use. Similarly, even when Microsoft informed IBM managers that it wanted to be able to sell the operating system to other firms, IBM failed to realize that software could actually be a profitable business. These corporate managers' prior knowledge, which was based on their work experience, industry exposure, and education, prevented them from recognizing the value of these new endeavors. In other words, managers' existing knowledge corridors adversely affected their ability to evaluate new business initiatives with an open mind. It would thus be incorrect to assume that everyone is equally and instantly capable of exploiting an opportunity once it is presented to them (Endres \& Woods, 2006). It seems that the secret to engaging in entre- 
preneurial behavior does not lie in information about new opportunities, but in making sense about themwhat Garud and Karnoe (2003) refer to as “interpretive asymmetries” (Garud \& Karnoe, 2003).

Finally, films may be particularly well-suited for entertainment education (Singhal \& Rogers, 2002) in entrepreneurship, as millions of viewers watch entrepreneurship-related films-for example, The Social Network (2010) and Risky Business (1983). While most people probably watch these films for entertainment, prior studies have shown that people are also impacted by the entrepreneurship-related information depicted in them (Bumpus, 2005; Champoux, 1999). In addition, according to the drench hypothesis (Greenberg, 1988), noteworthy or striking examples presented in films (e.g., Bill Gates and Steve Jobs in PSV ) can have a significant influence on viewer attitudes and perceptions. Social cognitive theory (e.g., Bandura, 1986) suggests that audience members can vicariously learn norms and behaviors from films, as people are far more likely to mimic a behavior they have seen rather than one that has been recommended but not demonstrated. Seeing someone who-like them-starts out small and overcomes tremendous obstacles to succeed in the face of adversity is likely to enhance students' beliefs in their abilities - or self-efficacy-with regard to entrepreneurial behavior.

\section{Limitations}

Notwithstanding our interesting findings, our study has certain limitations that suggest avenues for further research. First, our study uses data derived from a film officially based on the book titled Fire in the Valley: The Making of the Personal Computer by Paul Freiberger and Michael Swaine. It is possible that looking at the PC industry through a different worldview would uncover some different entrepreneurial behaviors not covered in the PSV-the "Rashoman effect," which posits that people see and describe reality based on their unique filters (Mittelmeier \& Friedman, 1991). Future research may use other texts about the PC industry's emergence, such as Accidental Empires (Cringley, 1992), or the 1996 PBS documentary derivative Triumph of the Nerds to further generate additional insights into entrepreneurial behavior.

Second, following prior research, we treated the two theoretical perspectives-discovery and creation-as distinct. Consequently, we did not consider the possibility of interaction between the two theories in our interpretation of the PSV episodes. It is possible that had we focused from the outset on the intersection between discovery and creation, we would have identified novel findings that were not uncovered by our current approach. Future research should consider the implications of interactions between discovery and creation as we found in our study.

Finally, our study is situated in the context of a technology-based industry. The extent to which the findings revealed here will generalize to other industries (e.g., non-technology industries such as management consulting) cannot simply be assumed, but needs to be carefully examined. Relatedly, the applicability of the theory used here and the findings obtained is limited to the United States. Whether our theoretical insights and empirical results hold promise for understanding industry emergence in other countries is a topic for future research.

\section{Conclusion}

This study was undertaken to explore and apply discovery and creation perspectives to the study of entrepreneurial behavior in an emerging industry. While prior research has done a masterful job of articulating the two perspectives (Alvarez \& Barney, 2007), our study addresses the next critical step in advancing this research stream: Extending discovery and creation approaches to generate insights into an important area that is in need of theoretical elaboration and empirical examination: entrepreneurial behavior during industry emergence (Bird \& Schjoedt, 2009). Although the use of entrepreneurial stories as text for qualitative entrepreneurship research has begun to gain traction in the literature (Gartner, 2007, 2010b), our study goes one step further and conducts a textual analysis of a film. Given the complexities associated with gaining access to historical data about industry emergence, qualitative research that analyzes texts (e.g., books, films, and magazines) may provide researchers with a unique window into what happened during a new industry's early years (Mezias \& Kuperman, 2001). Thus, our research advances knowledge about entrepreneurial behavior by capitalizing on wellregarded theoretical perspectives (Okhuysen \& Bonardi, 2011) and using an innovative methodology (Corner \& Paclovich, 2007) to better understand the complex and dynamic phenomenon of entrepreneurial behavior during industry emergence (Gartner, 2007).

We encourage future research to extend the knowledge frontier by studying industry emergence in other industrial and national contexts, using processtheoretic methods such as the one presented here and variance-theoretic methods that are more common in entrepreneurship research. Entrepreneurial behavior in emergent industries is an important research topic, one that merits further research attention using different methodological approaches. 


\section{References}

Ahl, H. \& Czarniawska, B. (2010). Many words about tea. ENTER, 1, 191-210.

Aldrich, H.E. \& Fiol, C.M. (1994). Fools rush in? The institutional context of industry creation. Academy of Management Review, 19, 645670.

Aldrich, H.E. \& Reuf, M. (2006). Organizations evolving. London: Sage.

Allen, T. (2007). A toy store(y). Journal of Business Venturing, 22, 628-636.

Alvarez, S.A. \& Barney, J.B. (2007). Discovery and creation: Alternative theories of entrepreneurial action, Strategic Entrepreneurship Journal, 1,11-26.

Alvarez, S.A. \& Barney, J.B. (2010). Entrepreneurship and epistemology: The philosophical underpinnings of the study of entrepreneurial opportunities. Academy of Management Annals, 4, 557-583.

Baker, T. (2007). Resources in play: Bricolage in the toy store(y). Journal of Business Venturing, 22, 694-711.

Baker, T., \& Nelson, R. E. (2005). Creating something from nothing: Resource construction through entrepreneurial bricolage. Administrative Science Quarterly, 50(3), 329-366.

Bandura, A. (1986). Social foundations of thought and action: A social cognitive theory. Englewood Cliffs, NJ: Prentice-Hall, Inc.

Baumol, W.J. (1968). Entrepreneurship in economic theory. American Economic Review, 58, 64-71.

Bergin, P. R. (2006). How well can the new open economy macroeconomics explain the exchange rate and current account?. Journal of International Money and Finance, 25(5), 675-701.

Berglund, H. (2007). Opportunities as existing and created: A study of entrepreneurs in the Swedish mobile Internet industry. Journal of Enterprising Culture, 15, 243-273.

Bird, B. \& Schjoedt, L. (2009). Entrepreneurial behavior: Its nature, scope, recent research, and agenda for future research. International Studies in Entrepreneurship, 24, 327-358.

Buchanan, J.M. \& Vanberg, V.J. (1991). The market as a creative process. Economics and Philosophy, 7, 167-186.

Bumpus, M. (2005). Using motion pitctures to teach management: Refocusing the camera lens through the infusion approach to industry. Journal of Management Education, 29, 792-815.

Busenitz, L.W. (1996). Research on entrepreneurial alertness: Sampling, measurement, and theoretical issues. Journal of Small Business Management, 34, 35-44.

Busenitz, L.W., West III, G.P., Shepherd, D., Nelson, T., Chandler, G.N., \& Zacharakis, A. (2003). Entrepreneurship research in emergence: Past trends and future directions. Journal of Management, 29, 285-308.

Champoux, J.E. (1999). Film as a teaching resource. Journal of Management Inquiry, 8, 206.

Chan, A. (2004). The Macintosh Phenomenon: celebrating twenty years of world's most adored desktop computers. HWM Singapore, 74-83.

Chiles, T.H., Bluedorn, A.C., \& Gupta, V.K. (2007). Beyond creative destruction and entrepreneurial discovery: A radical Aust rian approach to entrepreneurship. Organization Studies, 28(4), 467-493.

Chiles, T.H. \& Zarankin, T.G. (2005). A 'kaleidic' view of entrepreneurship: Developing and grounding radical Austrian economics' master metaphor. Paper presented at Academy of Management Annual Meeting.

Chiles, T.H., Vultee, D., Gupta, V.K., Greening, D., \& Tuggle, C. (2010a). The philosophical foundations of a radical Austrian approach to entrepreneurship. Journal of Management Inquiry, 19, 138-164.

Chiles, T.H., Tuggle, C.S., McMullen, J.S., Bierman, L., \& Greening, D.W. (2010b). Dynamic creation: Extending the radical Austrian approach to entrepreneurship. Organization Studies, 31, 7-46.

Corley, K.G. \& Gioia, D.A. (2011). Building theory about theory building: What constitutes a theoretical contribution? Academy of Management Review, 36, 12-32.

Corner, P.D. \& Pavlovich, K. (2007). Entrepreneurship research: Follow the yellow-brick road? Journal of Management \& Organization, 13, 288-294.

Cringley, R.X. (1992). Accidental Empires: How the Boys of Silicon Valley Make Their Millions, Battle Foreign Competition and Still Don't Get a Date. New York: Harper Paperbacks.

Day, G.S. (1994). The capabilities of market-driven organizations. The Journal of Marketing, 37-52.

De'Tienne, D.R. \& Chandler, G.N. (2004). Opportunity identification and its role in the entrepreneurial classroom: A pedagogical approach and empirical test. Academy of Management Learning \& Education, 3, 242-257.

Diesing, P. (1991). How does social science work? Pittsburgh: Pittsburgh Press. 
Edelman, L. \& Yli-Renko, H. (2010). The impact of environment and entrepreneurial perceptions on venture-creation efforts: Bridging the discovery and creation views of entrepreneurship. Entrepreneurship Theory and Practice, 34, 833-856.

Eisenhardt, K.M. \& Bourgeois, L.J. (1988). Politics of strategic decision making in high-velocity environments: Toward a midrange theory. Academy of Management Journal, 31, 737-770.

Eisenhardt, K.M. (1989). Making fast strategic decisions in high-velocity environments. Academy of Management Journal, 32, 543-576.

Eisenhardt, K.M., \& Graebner, M.E. (2007). Theory building from cases: Opportunities and challenges. Academy of Management Journal, 50, $25-32$.

Endres, A.M. \& Woods, C.R. (2006). Modern theories of entrepreneurial behavior: A comparison and appraisal. Small Business Economics, 26, 189-202.

Evans, P. \& Doz, Y. (1992). Dualities: A paradigm for human resource and organizational development in complex multinationals. In V. Pucik, N. Tichy, \& C. Barnett (Eds), Globalizing management: Creating and leading the competitive organization. New York: Wiley.

Fiet, J.O. (1996). The informational basis of entrepreneurial discovery. Small Business Economics, 8, 419-427.

Fletcher, D. (2007). 'Toy story': The narrative world of entrepreneurship and the creation of interpretive communities. Journal of Business Venturing, 22, 649-672.

Forbes, D.P. \& Kirsch, D.A. (2011). The study of emerging industries: Recognizing and responding to some central problems. Journal of Business Venturing, in press.

Foss, K., Foss, N. J., Klein, P. G., \& Klein, S. K. (2007). The entrepreneurial organization of heterogeneous capital. Journal of Management Studies, 44(7), 1165-1186.

Freeman, M.L. \& Valentine, D.P. (2004). Through the eyes of Hollywood: Images of social workers in film. Social Work, 4,151-161.

Gaglio, C. M., J. A. Katz. (2001). The psychological basis of opportunity identification: Entrepreneurial alertness. Small Business Economics, 16(2), 95-111.

Gates, W. (2010). Remembering Ed Roberts. April 01. Available at www.thegatenotes.com

Gartner, W.B. (2007). Entrepreneurial narrative and a science of the imagination. Journal of Business Venturing, 22, $613-627$.

Gartner, W.B. (2010a). A new path to the waterfall: A narrative on a use of entrepreneurial narrative. International Small Business Journal, 28, 6-19.

Gartner, W.B. (2010b). An entrepreneurial jeremiad. ENTER, 1, 1-13.

Garud, R., Jain, S., \& Kumaraswamy, A. (2002). Institutional entrepreneurship in the sponsorship of common technological standards: The case of Sun Microsystems and Java. Academy of Management Journal, 45(1), 196-214.

Garud, R. \& Karnoe, P. (2003). Bricolage versus breakthrough: Distributed and embedded agency in technology entrepreneurship. Research Policy, 32, 277-300.

Gloria-Palermo, S. (1999). The Evolution of Austrian Economics: From Menger to Lachmann. Routledge: London.

Graetz, F. \& Smith, A.C.T. (2007): The role of dualities in arbitrating continuity and change in forms of organizing. International Journal of Management Reviews, 9, 1-16.

Greenberg, B. S. (1988). Some uncommon television images and the Drench hypothesis. Applied Social Psychology, 8, 88-102.

Hill, C.W., \& Deeds, D.L. (1996). The importance of industry structure for the determination of firm profitability: A neo-Austrian perspective. Journal of Management Studies, 33(4), 429-451.

Hjorth, D. \& Johannisson, B. (2008). Building new roads for entrepreneurship research to travel by: On the work of William B. Gartner. Small Business Economics, 31, 341-350.

Hjorth, D., Jones, C., \& Gartner, W.B. (2008). Introduction for 'recreating/recontextualising entrepreneurship. Scandinavian Journal of Management, 21, 81-84.

Holcombe, R.G. (1999) . "Equilibrium versus the invisible hand.” Review of Austrian Economics, 12(2), $227-243$.

Holcombe, R.G. (2003). The origins of entrepreneurial opportunities. Review of Austrian Economics, 16, $25-43$.

Huff, R. (1999). Titans of computing. New York Daily News, June 20.

Jackson, M., Mandeville, T., \& Potts, J. (2002). The evolution of the digital computation industry. Prometheus, 20, 323-336.

Jasper, D. (2004). A short introduction to hermeneutics. Louisville: Westminster John Knox Press.

Jobs, S. (2005). Commencement Speech, Stanford University, CA.

Karlgaard, R. (2006): You can predict the future. Forbes, 177(2), 33.

Katz, J. \& Gartner, W.B. (1988). Properties of emerging organizations. Academy of Management Review, 13, $429-441$.

Kirzner, I. (1973). Competition and Entrepreneurship. Chicago: University of Chicago Press. 
Kirzner, I.M. (1997). Entrepreneurial discovery and the competitive market process: An Austrian approach. Journal of Economic Literature, $35,60-85$.

Klein, H.K. \& Myers, M.D. (1999). A set of principles for conducting and evaluating interpretive field studies in information systems. MIS Quarterly, 23, 67-93.

Klein, P.G. (2008). Opportunity discovery, entrepreneurial action, and economic organization. Strategic Entrepreneurship Journal, 2, 175-190.

Klepper, S. \& Graddy, E. (1990). The evolution of new industries and the determinants of market-structure. Rand Journal of Economics, 21, 27-44.

Kor, Y.Y., Mahoney, J.T., \& Michael, S.C. (2007). Resources, capabilities and entrepreneurial perceptions. Journal of Management Studies, 44, $1187-1212$.

Korsgaard, S. \& Neergaard, H. (2011). Sites and enactments: A nominalist approach to opportunities. ENTER, 1, 137-152.

Krueger, N.F., O'Reilly, M., \& Carsrud, A. (2000). Competing models of entrepreneurial intentions. Journal of Business Venturing, 15, 411-432.

Lee, B., Sine, W.D., \& Tolbert, P. (2011). Certifying the harvest: The role of standards-based certification organizations in the organic food industry, under review.

Leonard, J. (1999). Television review: Pirates of Silicon Valley. New York Magazine, June 21.

Lévi-Strauss, C. (1967). The Savage Mind. Chicago: University of Chicago Press.

Levy, S. (1994). Insanely Great: The life and times of Macintosh, the computer that changed everytbing. New York, Viking.

Levy, S. (2007). The future of reading. Newsweek, Nov. 17.

Lewis, M.W. (2000). Exploring paradox: Toward a more comprehensive guide. Academy of Management Review, 25, 760-776.

Loasby, B.J. (1992). Business organization and the myth of the market economy. Cambridge: Cambridge University Press.

Low, M.B., \& Macmillan, I.C. (1988). Entrepreneurship: Past research and future challenges. Journal of Management, 14, 139-161.

Low, M.B. (2001). The adolescence of entrepreneurship research: Specification of purpose. Entrepreneurship Theory and Practice, $25,17-25$.

Lunce, S.E. \& Smith, S.A.M. (2005). Business in the media: A pedagogical approach to understanding basic business concepts. International Journal of Innovation and Learning, 2, 210-222.

Macmillan, I.C. \& Katz, J.A. (1992). Idiosyncratic milieus of entrepreneurial research: The need for comprehensive theories. Journal of Business Venturing, 7, 1-8.

Mathews, J.A. (2010). Lachmannian insights into strategic entrepreneurship: Resources, activities and routines in a disequilibrium world. Organization Studies, 31, 219-244.

Maguire, S., Hardy, C., \& Lawrence, T. B. (2004). Institutional entrepreneurship in emerging fields: HIV/AIDS treatment advocacy in Canada. Academy of management journal, 47(5), 657-679.

Mezias, S.J. \& Kuperman, J.C. (2001). The community dynamics of entrepreneurship: The birth of the American film industry, 18951929. Journal of Business Venturing, 16, 209-233.

Miller, K.D. (2007). Risk and rationality in entrepreneurial processes. Strategic Entrepreneurship Journal, 1, 57-74.

Mittelmeier, C., \& Friedman, S. (1991). The" Rashomon effect": A study in constructivist conversation. Family Therapy.

Moritz, M. (1984). The Little Kingdom: The Private Story of Apple Computer. William Morrow \& Co.

Mumford, M.D. \& Van Doorn, J.R. (2001). The leadership of pragmatism: Reconsidering Franklin in the age of charisma. Leadership Quarterly, 12, 279-309.

Mumford, M.D. (2002). Social innovation: Ten cases from Benjamin Franklin. Creativity Research Journal, 14, 253-266.

Myers, M.D. (2009). Qualitative research in business \& management. London: Sage.

Neergaard, H. (2007). Sampling in entrepreneurial settings. In H. Neergard (Ed.), Handbook of Qualitative Research Methods in Entrepreneurship (pp. 253-278). Northampton: Edward Elgar Publishing.

Neuendorf, K.A., Gore, T.D., Dalessandro, A., Janstova, P., \& Snyder-Suhy, S. (2010). Shaken and stirred: A content analysis of women's portrayals in James Bond films. Sex Roles, 62, 747-761.

O’Driscoll, G.P. \& Rizzo, M.J. (1985). The economics of time and ignorance. Oxford: Blackwell.

Okhuysen, G. \& Bonardi, J. (2011). Editors' comments: The challenges of building theory by combining lenses. Academy of Management Review, 36, 6-11.

Pacheco, D.F., Dean, T.J., \& Payne, D.S. (2010). Escaping the green prison: Entrepreneurship and the creation of opportunities for sustainable development. Journal of Business Venturing, 25, 464-480.

Phillips, N. \& Brown, J. L. (1993). Analyzing communication in and around organizations: A critical hermeneutic approach. Academy of Management Journal, 36, 1547-1576. 
Rao, H. (2004). Institutional activism in the early American automobile industry. Journal of Business Venturing, 19, $359-384$.

Ricoeur, P. (Ed.). (1981). Hermeneutics and the human sciences: essays on language, action and interpretation. Cambridge: Cambridge University Press.

Rivlin, G. (1999). Windows dressing searching Silicon Valley for somebody, anybody, who cares about the Microsoft ruling. New Republic, 11-11.

Rudy, R.M., Popova, L., \& Linz, D.G. (2010). The context of current content analysis of gender roles: An introduction to a special issue. Sex Roles, 62, 705-720.

Santos, F.M. \& Eisenhardt, K. M. (2009). Constructing markets and shaping boundaries: Entrepreneurial power in nascent fields. Academy of Management Journal, 52, 643-671.

Sarasvathy, S.D. (2001). Causation and effectuation: Toward a theoretical shift from economic inevitability to entrepreneurial contingency. Academy of Management Review, 26, 243-263.

Sarasvathy, S.D., Dew, N., Velamuri, S.R., \& Venkataraman, S. (2003). Three views of entrepreneurial opportunity. In Z.J. Acs \& D.B. Audretsch (Eds.), Handbook of entrepreneurship research: An interdisciplinary survey and introduction (pp. 141-160). Dordrecht, the Netherlands: Kluwer Academic Publishers.

Scholes, R. (1980). Afterthoughts on narrative: Language, narrative, and anti-narrative. Critical Inquiry, 7, $204-212$.

Shane, S. (2000). Prior knowledge and the discovery of entrepreneurial opportunities. Organization Science, 11, $448-469$.

Shane, S. (2003). A general theory of entrepreneurship: The individual-opportunity nexus. Massachusetts: Edward Elgar Publishing.

Shane, S. \& Venkataraman, S. (2000). The promise of entrepreneurship as a field of research. Academy of Management Review, $25,217-226$.

Simmons, G. J. (2007). “i-Branding”: Developing the Internet as a branding tool. Marketing Intelligence \& Planning, $25(6), 544-562$.

Sine, W.D., Haveman, H.A., \& Tolbert, P.S. (2005). Risky business? Entrepreneurship in the new independent-power sector. Administrative Science Quarterly, 50, 200-232.

Sine, W.D. \& Lee, B.H. (2009). Tilting at windmills? The environmental movement and the emergence of the US wind energy sector. Administrative Science Quarterly, 54, 123-155.

Singhal, A. \& Rogers, E.M. (2002). A theoretical agenda for entertainment-education. Communication Theory, 12, 117-135.

Steyaert, C. (2007). 'Entrepreneuring' as a conceptual attractor? A review of process theories in 20 years of entrepreneurship studies. Entrepreneurship and Regional Development, 19, 453-477.

Tan, H., Wilson, A., \& Olver, I. (2009). Ricoeur's theory of interpretation: An instrument for data interpretation in hermeneutic phenomenology. International Journal of Qualitative Methods, 8, 18-37.

Taylor III, A.L., Moritz, M., \& Stoler, P. (1984). The wizard inside the machine. Time 123,(16), 42-49.

Teague, B.T. (2010). A narrative analysis of idea initiation in The Republic of Tea. ENTER, 1, 169-190.

Thompson, J.B. (1984). Critical hermeneutics: A study in the thought of Paul Ricoeur and Jürgen. Cambridge: Cambridge University Press.

Utterback, J.M. \& Suarez, F.F. (1993). Patterns of industrial evolution, dominant designs, and firms' survival. In R. S. Rosenbloom (Ed.), Research on technological innovation, management and policy (pp. 47-87). Greenwich, Conn. and London: JAI Press.

Vaghely, I.P. \& Julien, P.A. (2010). Are opportunities recognized or constructed? An information perspective on entrepreneurial opportunity identification. Journal of Business Venturing, 25, 73-86.

Valdez, A. \& Halley, J.A. (1999). Teaching Mexican American experiences through film: Private issues and public problems. Teaching Sociology, 27, 286-295.

Van de Ven., A.H. \& Engleman, R.M. (2004). Event- and outcome-driven explanations of entrepreneurship. Journal of Business Venturing, 19, 343-358.

Vaughn, K.I. (1992). The problem of order in Austrian economics: Kirzner vs. Lachmann. Review of Political Economy, 4, $251-274$.

Wallace, J. (1993), Hard Drive: Bill Gates and the Making of the Microsoft Empire. New York: HarperCollins Publishers.

Weick, K.E. (1995). Sensemaking in organizations. Thousand Oaks, CA: Sage.

Wozniak, S. (2000). Letters-questions regarding Pirates of Silicon V alley answered. Available at woz.org.

Wozniak, S., \& Smith, G. (2006). iWoz: Computer Geek to Cult Icon: How I Invented the Personal Computer, Co-founded Apple, and Had Fun Doing It. New York, NY: Norton \& Co.

Zahra, S.A. (2008). The virtuous cycle of discovery and creation of entrepreneurial opportunities. Strategic Entrepreneurship Journal, 2, $243-257$. 


\section{Acknowledgment}

This article benefited from comments and suggestions provided by conference attendees at the Eastern Academy of Management. A prior version of this article was presented at the 2012 International Council for Small Business Conference in New Zealand where it received the Best Paper Award in Methodology and Theory Development track. The authors thank special issue editor Golshan Javadian and anonymous NEJE reviewers for critical feedback and suggestions during the review process. All errors and omissions remain our own.

\section{About the Authors}

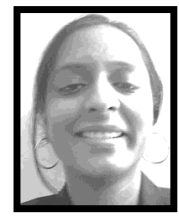

ALKA GUPTA (Gupta.A2@lynchburg.edu) is an Assistant Professor in the School of Business and Economics at Lynchburg College. She received her Ph.D. in Business Administration (concentration in Organizational Behavior and Leadership) from State University of New York at Binghamton. Her research interests include entrepreneurial orientation and focus on decision-making dynamics under crisis situations. She has published in journals such as Organization Research Methods and Leadership Quarterly.

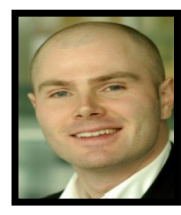

CHRISTOPH K. STREB (christoph.streb@uni.lu) earned his Ph.D. at the Jacobs University Bremen (Germany) before taking up a professorship at the University of Groningen (The Netherlands), next to extended visiting professorships in China, India, Peru, and Egypt. During his career he has engaged in several entrepreneurial activities on a multinational level, in the automotive, software, and publishing industries. He also serves on the advisory board of a number of distinguished companies. At his current position at the University of Luxembourg, he is researching the intersection of entrepreneurship and material culture from a business historical/archaeological perspective.

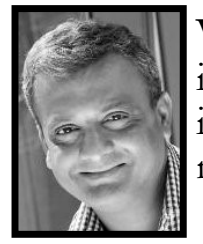

ViSHAL K. GUPTA (vgupta@bus.olemiss.edu) is Associate Professor in the School of Business Administration at the University of Mississippi. He received his Ph.D. in Strategic Management (with emphasis in Entrepreneurship) from the University of Missouri. His professional experience includes starting or managing businesses in machine tools, automobile ancillaries, and vocational training sectors.

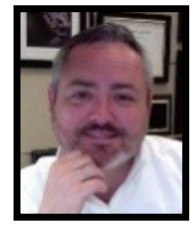

ERIK MARKIN is a doctoral student of Management at the University of Mississippi. His areas of interest include entrepreneurship and family business. He has owned and operated multiple small businesses, a small business consultation, and instructed economics at the university level. 